\title{
Human trafficking for sex, labour and domestic servitude: how do key trafficking types compare and what are their predictors?
}

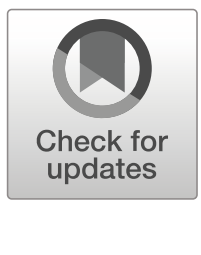

\author{
Ella Cockbain ${ }^{1}$ (D) Kate Bowers ${ }^{1}$
}

Published online: 25 April 2019

(C) The Author(s) 2019

\begin{abstract}
Combatting trafficking in human beings is a well-established social policy and crime prevention priority for the twenty-first Century. Human trafficking, as defined in international law, can occur for diverse exploitative purposes. Yet, different forms of trafficking are routinely conflated in research, policy and interventions. Most of the attention to date has been on sex trafficking of women and girls, leaving male victims and other trafficking types comparatively overlooked. In this study, we disentangle differences between key trafficking types using rare individual-level data from the United Kingdom's central system for identifying trafficking victims. For a sample of 2630 confirmed victims, we compare those trafficked for sex, domestic servitude and other labour across variables relating to victim demographics, the trafficking process and official responses. Having established significant and substantial differences at bivariate level, we use multinomial logistic regression to identify predictors of trafficking type. Overall, our results underline the complexity and diversity of human trafficking and warn against conflating different types. Within a holistic counter-trafficking framework, a more disaggregated and nuanced approach to analysis and intervention is vital in ensuring more finely-targeted responses. This original study has clear lessons for research, policy and practice.
\end{abstract}

\section{Introduction: A skewed focus, conflated problems and pronounced knowledge gaps}

Human trafficking can take many forms: diverse people may be moved within or between countries by various means for different purposes, including sexual exploitation, organ harvesting, domestic servitude (work in private households) and exploitation in numerous other licit and illicit labour markets. Despite this inherent diversity,

Ella Cockbain

e.cockbain@ucl.ac.uk

1 Department of Security and Crime Science, University College London (UCL), London, UK 
the focus of the trafficking field has long been skewed towards sexual exploitation and specifically that of women and girls. Indeed, when the international community came together in the late 1990s to agree a definition of human trafficking that would inform national legislation, harmonise responses and improve international coordination, the result was the 'Protocol to Prevent, Suppress and Punish Trafficking in Persons, especially Women and Children' [Italics added for emphasis] [75]. This definition $^{1}$ (the 'Palermo Protocol') has shaped most national legislation [80] and is widely used in research, including this study and its underlying data. In the years following Palermo, the international community continued to focus primarily on sex trafficking [35]. Similar was (and to a large extent still is) true at national level; for example, several countries' annual human trafficking reports and statistics initially dealt only with sex trafficking [12]. In the United States (US) (e.g. [4, 32]), numerous European countries (e.g. [2, 45, 58, 63]) and elsewhere, responses to trafficking for purposes other than sex remain comparatively underdeveloped.

Some researchers attribute the dominant focus on sexual exploitation and associated gendering of the trafficking discourse to its roots in widespread (and since debunked) panic about the 'white slave trade' in the early twentieth Century [24, 25, 48]. In New York, for example, concerns about the alleged large-scale abduction and sale of (white) women and girls by 'foreigners' for prostitution ${ }^{2}$ proved the defining issue of the 1909 elections [48]. Early attempts to investigate the 'white slave trade' came amid a broader campaign for 'social hygiene', entwined with an abolitionist stance on prostitution, a moralising agenda, xenophobia and fears of racial contamination [48]. As concerns escalated internationally over the first part of the twentieth Century, various international conventions were adopted that focused on protecting women and children (more accurately, girls) from prostitution ${ }^{3}[35]$.

The historic tendency to conflate human trafficking with sex trafficking and that in turn with all sex work/prostitution persists today. This conflation is most obvious among the religious right and 'abolitionist feminist" lobby in the US, whom Weitzer [83] describes as co-opting human trafficking in a 'moral crusade' against prostitution. A notable recent development was the enactment of FOSTA-SESTA legislation in 2018: although the law purportedly tackles internet-enabled sex trafficking (the acronyms stand respectively for 'Allow Victims to Fight Online Sex Trafficking Act' and

\footnotetext{
1 “Trafficking in persons' shall mean the recruitment, transportation, transfer, harboring, or receipt of persons, by means of the threat or use of force or other forms of coercion, of abduction, of fraud, of deception, of the abuse of power, or of a position of vulnerability or of the giving or receiving of payments or benefits to achieve the consent of a person having control over another person, for the purpose of exploitation. Exploitation shall include, at a minimum, the exploitation of the prostitution of others or other forms of sexual exploitation, forced labour or services, slavery or practices similar to slavery, servitude or the removal of organs' [73]. Note that children (under 18 year-olds) are a special case since they are deemed incapable of giving informed consent so can be classed as trafficked even where no 'means' is present [28, 74].

${ }^{2}$ Language around the sale of sex is divisive and highly charged. The term 'prostitution' still underpins much national law and policy but has been criticised for implying a fundamental lack of agency and bodily autonomy. We have tried to choose our language carefully and precisely, referring variously to 'sex work', 'prostitution' and 'sexual exploitation' depending on the specific context.

${ }^{3}$ For example, the League of Nations' 1921 'International Convention for the Suppression of the Traffic in Women and Children' and the United Nations' 1949 'Convention on the Suppression of Trafficking in Women and the Exploitation of Prostitution of Others'

4 'Abolitionist feminist' refers to those taking the essentialist position that prostitution is inherently exploitative and an instrument of male domination and must therefore be eradicated (see [83]).
} 
'Stop Enabling Sex Traffickers Act'), critics argue that its effectiveness has been overstated and it has pushed sex trafficking further underground and harmed consenting sex workers (see, e.g. [9, 69]). Similar tensions have been evident in the UK recently, with some politicians framing prostitution as de facto commercial sexual exploitation and overstating the evidence on its overlap with trafficking [3, 38], seemingly to galvanise support for controversial legislative reforms around the advertising and sale of sex (see, e.g. [9]).

With human trafficking and interconnecting territory so emotive and politicised, it is unsurprising that 'wild claims' [86] and 'sketchy data' [35] can fill the void left by the dearth of rigorous empirical research. The past two decades have seen multi-million dollar investment in counter-trafficking and a pronounced increase in policy-making, legislation, research and practical interventions worldwide (e.g. [37, 42, 62, 84]). Yet, for all this activity there has been remarkably little robust data-driven research on human trafficking and how best to tackle it $[12,50,71,81,85]$. Other longstanding criticisms of the trafficking literature include its limited scope, spurious statistics, methodological opacity and weaknesses, dubious assumptions and exaggerated and ill-substantiated claims $[12,35,37,50,71,85]$. One of the most enduring, pronounced and widely recognised skews in the literature is its overwhelming focus on sex trafficking at the expense of other types, such as trafficking for domestic servitude and other forms of labour exploitation [1, 12, 37, 47, 50, 67].

While the vast majority of trafficking cases identified globally in the early twentyfirst Century involved sexual exploitation, the past decade has seen a marked shift [78]. Indeed, some experts argue that that labour trafficking may actually be more prevalent than sex trafficking but has likely been comparatively under-detected so far-and thus is underrepresented in official statistics (e.g., [77, 85]). Using data from a combination of sources, the most recent United Nations Global Report on Trafficking in Persons reported a total of 19,929 identified victims in 2014 across 81 countries and all trafficking types [78]. Such identified cases undoubtedly represent just a fraction of the true trafficking problem (see, e.g., [19]). Notably, the report highlighted the changing composition of cases identified between 2004 and 2014. For example, the proportion of male victims and child victims both increased over this period (respectively from $13 \%$ to $21 \%$ and $13 \%$ to $28 \%$ ) and the share of sex trafficking victims fell (from 59\% to 54\%). These and other such changes are thought to reflect an evolution in how human trafficking is understood and a move away from the dominant focus on 'women trafficked from afar into an affluent country for sexual exploitation' ([78], p.6). The report also found clear variations between regions in the types of trafficking identified, demonstrating that '[g]lobal averages mask marked regional differences' and highlighting the need for geographically-specific enquiries ([78], p.24).

The current study focuses on the UK, which is an affluent country and wellrecognised destination for international trafficking. It is also comparatively advanced in terms of its counter-trafficking responses - although tensions exist between aspirations towards global anti-slavery leadership and the realities of austerity, harsh immigration policies, rising xenophobia etc [52]. The UK government last estimated that there were 10,000-13,000 victims of trafficking in the UK [64], although these figures are now dated and likely underestimate the true prevalence. Over the past decade, the UK has seen both a steady increase in the volume of suspected trafficking identified and diversification in the forms of exploitation involved [18]. In 2006/2007, all 
identified victims of trafficking in the UK were subject to sexual exploitation [77]. In $2017,34 \%$ of of suspected victims of modern slavery ${ }^{5}$ referred to the National Crime Agency were linked to sexual exploitation, $46 \%$ to labour exploitation and 9\% to domestic servitude [53]. The total number of referrals received annually virtually tripled between $2013(n=1745)$ and $2017(n=5145)$. Meanwhile, police in England and Wales recorded 3337 modern slavery offences in the year to end March 2018, up $49 \%$ on the previous year [56] (police in Scotland and Northern Ireland recorded another 60 and 31 respectively, see [39]). Since the police recorded crime data are published in the aggregate it is unclear how these offences were distributed across different forms of trafficking and exploitation.

Both nationally and transnationally, impetus is growing to improve understanding and responses to all forms of human trafficking, not just sex trafficking (e.g., [27, 36, $44,72]$ ). Indicative of a shift towards treating human trafficking as a broader labour market issue, the United Nations [76] positioned its target of taking 'immediate and effective measures to.. end modern slavery and human trafficking' under its Sustainable Development Goal of 'decent work and economic growth'.

It is increasingly clear that human trafficking belongs on a broader spectrum of exploitation, coercion and consent, rather being than a neatly delineated phenomenon that exists in absolute terms $[50,55,61,65,66,84]$. The breadth and inclusivity of trafficking definitions leave obvious scope for inconsistency in their interpretation and operationalisation, whereby factors including individuals' and agencies' experiences, priorities and awareness can affect what is identified and recorded as trafficking $[8,10$, $19,31,32,60]$. Such considerations notwithstanding, much can be learnt by examining instances identified as human trafficking to advance understanding of this complex phenomenon and support more nuanced and evidence-informed policy and practice (see also [10]).

There are solid theoretical and empirical reasons to hypothesise that differences exist between victims of different types of trafficking, for example in terms of their sociodemographic characteristics, trafficking experiences and official responses. From a theoretical perspective, opportunity theories of crime help explain why crimes are not uniformly distributed but rather concentrate in certain places, times, people and targets (see, e.g. $[6,7,20,30,33,34])$. Understanding the distribution of specific crime types (often within a general category, such as distinguishing between residential and commercial burglary) can help provide insights into their drivers and enablers and inform targeted interventions. The rational choice perspective positions offenders as quasirational decision makers who act to maximise rewards, while minimising risks [21]. In this respect, one would expect the different market realities (gaps, demands etc.) of the sex industry, domestic servitude and other labour markets to influence who traffickers recruit and where and how they exploit them.

National and international statistical data highlight important empirical distinctions between the different trafficking types. A classic example is gender: in the UK and internationally, the proportion of men is typically far higher among those identified as

\footnotetext{
${ }^{5}$ Particularly in affluent Anglophone countries - like the UK, United States and Australia - there has been a shift towards repackaging trafficking as 'modern slavery': an even broader umbrella construct that encompasses other forms of exploitation too [55]. We focus here on human trafficking as our data predate legislative change in the UK (Modern Slavery Act 2015 and similar laws in the devolved nations).
} 
trafficked or potentially trafficked for labour than for sex (e.g. [29, 53, 78]). Yet, published comparisons of trafficking types tend to be purely descriptive and made only at a bivariate level; inferential statistics are rarely used to test the relationships observed. These limitations are reflective of wider shortcomings in the trafficking literature, namely the scarcity of robust quantitative research $[12,50]$. One of the biggest barriers academics face in conducting quantitative research into the differences between trafficking types is securing access to large-scale, individual-level datasets. Taking a qualitative approach, Efrat [26] examined policy responses to the main forms of human trafficking encountered in Israel (sex, labour and organ trafficking) and concluded that ' $[\mathrm{b}] \mathrm{y}$ disregarding the differences between these phenomena and bundling them into a single concept, we compromise the analysis and design of counter-trafficking efforts' [26].

We designed the current study to investigate empirically and at scale whether significant differences exist between the three main categories of human trafficking encountered in the UK: trafficking for sexual exploitation, domestic servitude and other labour exploitation (hereafter simply 'labour trafficking'). We address in turn two broad-based and interlinked research questions:

- What (if any) are the differences between these three trafficking types, in terms of individual victims' demographics, the trafficking process and official responses?

- Which (if any) of these variables predict trafficking type?

\section{Methods}

\section{Data}

Our data came from the UK's central system for managing suspected cases of human trafficking: the National Referral Mechanism (NRM). Introduced to fulfil the UK's obligations under the Council of Europe's [22] Convention on Action against Trafficking in Human Beings, the NRM is a framework to standardise the identification of victims and provision of support services [54]. At the time, the NRM dealt only with human trafficking, although it has since been expanded to include other forms of modern slavery [40]. For context, we briefly explain how the NRM currently works. Referrals are made in a standard proforma by authorised 'first responders', such as law enforcement, social services and certain non-governmental organisations (NGOs). First responders may have identified potential victims themselves or been notified by thirdparties (e.g. embassy staff). The National Crime Agency (NCA) initially assesses all referrals: depending on suspected victims' immigration status, their cases are then processed by the NCA or transferred to UK Visas and Immigration (UKVI). The decision-making follows two stages; only those with a positive final ('conclusive grounds') decision are officially considered trafficking victims.

Our data came from the central repository (spreadsheet) managed by the NCA, which routinely informs official reports but had not previously been made available to academics. It contains detailed individual-level data on everyone referred into the NRM. The NCA provided us anonymised data covering 6858 suspected victims of trafficking: the total population of referrals into the NRM from its inception on 1st April 2009 to the date of extraction on 7th October 2014. 


\section{Final study sample}

We narrowed down the initial set of 6858 suspected victims to our final study sample. Since our focus was on those officially identified as victims, we began by excluding people assessed not to have been trafficked, for whom a decision was still pending, or whose referral had been withdrawn or suspended $(n=4131)$. Notably, very similar proportions had been assessed to have been trafficked as not (39.8\% versus $40.6 \%){ }^{6}$ Next, we excluded those listed as trafficked for an 'unknown' purpose $(n=95)$ (not relevant) or for organ harvesting $(n=2)$ (too few for analysis). Our final study sample comprised 2630 confirmed cases of trafficking for sexual exploitation, domestic servitude and other labour exploitation over the 5.5 year period. Note that the UK treats domestic servitude as a separate category rather than subsuming it under labour trafficking as some other countries do (see [12]). The UK does so, to our knowledge, because of domestic servitude's particular characteristics and challenges: for example, it is especially hidden (out of sight in private households), poorly-understood, less obviously and immediately associated with 'organised crime' and poses additional barriers to intervention $[5,18,60]$. The 'labour trafficking' category as used in the UK is still broad, however, and covers exploitation across diverse licit and illicit industries (e.g. agriculture, factory work, construction, hospitality, benefit fraud, forced or sham marriages, organised shoplifting, cannabis cultivation etc.)

\section{Analysis}

We cleaned and recoded the raw data, excluding some variables because of high rates of missing data, overlaps with other variables or limited relevance. Due to missing data, we had to drop several variables of clear research interest, such as mode of transport and port of entry. Table 1 shows the final variables used in our analyses, grouped by category. For all of these variables bar one, complete information was available for $\geq 99 \%$ of cases. The variable 'exploitation type' captured the main purpose for which had been trafficked and formed the basis for comparing the three trafficking types.

We began with an exploratory data analysis [70], examining patterns descriptively and testing whether any differences between trafficking types were significant at the bivariate level. We then ran a multinomial logistic regression analysis to establish which variables were significant predictors of trafficking type (the outcome variable). We had to exclude from the regression analysis cases from the two least common regions (non-EEA Europe: $n=202$; and the Americas: $n=10$ ) since quasi/complete separation was present. Further cases $(n=296)$ were automatically excluded because of missing information on one or more variables in the model.

\section{Risk of bias}

We consider the study's general limitations in the discussion but - due to the complexities of the NRM data and their collection process - it is appropriate to flag several sources of potential bias specific to our data before presenting the results, First, the

\footnotetext{
$\overline{{ }^{6} \text { The rest had decisions pending }}(13.0 \%, n=893)$ or had been withdrawn, suspended or otherwise stalled $(6.6 \%, n=454)$. 
Table 1 Variables used in the analysis

\begin{tabular}{|c|c|c|}
\hline $\begin{array}{l}\text { Variable related } \\
\text { to the characteristics of... }\end{array}$ & Name & $\begin{array}{l}\text { Percentage of cases } \\
\text { with complete information }\end{array}$ \\
\hline \multirow[t]{4}{*}{ The individual victim } & Age in years & $99.51 \%(n=2617)$ \\
\hline & Gender & $100 \%(n=2630)$ \\
\hline & Nationality & $99.96 \%(n=2629)$ \\
\hline & Region of origin & $99.96 \%(n=2629)$ \\
\hline \multirow[t]{2}{*}{ The trafficking process } & Exploitation type & $100 \%(n=2630)$ \\
\hline & Police region where presented in the UK & $89.51 \%(n=2354)$ \\
\hline \multirow[t]{4}{*}{ Official responses } & Year of referral & $100 \%(n=2630)$ \\
\hline & Month of referral & $100 \%(n=2630)$ \\
\hline & Source of the referral & $99.01 \%(n=2604)$ \\
\hline & Time from referral to final decision (in days) & $98.90 \%(n=2601)$ \\
\hline
\end{tabular}

NRM captures only a proportion (of unknown size) of all trafficking in the UK [43, 64]. The number of potential victims referred into the system is likely affected by factors such as: awareness and understanding of both trafficking and the NRM; funding and prioritisation; and potential victims' willingness to engage [19]. Second, without knowing whether and how cases referred into the NRM differ from those that go undetected/unreported, the representativeness of the data is unclear [19]. Victims who do not conform to stereotypes of trafficking victims (e.g. male victims of sex trafficking) may be less likely to be identified as such. Also, adults, unlike children, must consent to referral so there may be some self-selection bias. Third, the UKVI has been said to be less willing than the NCA to deem people trafficking victims [51, 68], which could have introduced systematic bias based on nationality. Fourth, the dataset involves unique cases but not unique individuals: in those (relatively rare $^{7}$ ) instances where individuals are referred into the NRM more than once, they appear as a new entry. Working with anonymised data meant we could not filter out any such duplicates. Fifth, victims may be connected to one another, which violates the assumption of independence. Since links between cases were not systematically flagged in the data structure, we could not establish the extent of clustering and introduce statistical controls for its possible effects. Given the large dataset, unless any such clustering was very prevalent it is unlikely to have affected the validity of the findings. Finally, as is common when working with secondary data collected for non-research purposes (see, e.g., $[14,15]$ ), we were naturally constrained by the contents, categories and completeness of the original data and any other biases (e.g self report bias) they may have contained. We cannot rule out the existence of confounding variables not captured in our dataset. While it is important to be aware of these limitations and accordingly exercise caution in interpreting our results, the data nevertheless offer many strengths over other sources and meaningful analysis is possible.

\footnotetext{
${ }^{7}$ It is unknown how often repeat referrals occur across the NRM. In an on-going study, however, we found .> $1 \%$ of 453 victims of labour trafficking were repeat referrals.
} 


\section{Ethics}

This study was approved by the UCL Research Ethics Committee (reference: 5160/001).

\section{Results}

In this section, we present in turn the results of the exploratory data analysis and the logistic regression analysis.

\section{Initial comparison of trafficking types}

Here, we explore how the different trafficking types compared across the key variables in Table 1 for the overall study sample $(n=2630)$. The largest category was labour trafficking (45.2\%, $n=1188)$, followed shortly by sex trafficking $(42.1 \%, n=1106)$. Substantially fewer victims were trafficked for domestic servitude $(12.8 \%, n=336)$. Given these size differences, we tend to present results in percentage terms to facilitate comparison.

\section{Victims' age}

Victims' age distribution varied markedly between trafficking types. While the overall median age was 25.2 years, victims of sex trafficking were on average younger (median 22.8 years, range 10.4-54.8 years) than victims of domestic servitude (median 25.2 years, range 6.2-66.9 years) and, especially, of labour trafficking (median 29.2 years, range 0.384.5 years). Note that all labour trafficking victims aged seven or under were linked to benefit fraud, explaining the presence of infants and young children in this category. Figure 1 shows a much flatter age distribution for labour trafficking, whereas sex trafficking had obvious clustering in the late teens and early twenties and swift decline thereafter. A Kruskal-Wallis test demonstrated that the age differences between types were significant $\left(\chi^{2}=166.85, \mathrm{df}=\right.$ $2, p<0.001)$, although the epsilon squared value of 0.06 suggested a weak relationship.

\section{Gender}

Although the NRM data also contained categories such as transgender, all victims in our study sample fell within the male/female binary. While $62.2 \%(n=1625)$ of the overall sample was female, disaggregating the data revealed pronounced distinctions between trafficking types: female victims made up the overwhelming majority of victims for both sex trafficking $(97.3 \%, n=1076)$ and domestic servitude $(86.6 \%, n=291)$ but under a quarter $(22.6 \%, n=268)$ for labour trafficking. A chi-square test showed that gender differences between trafficking types were significant $(\chi 2=1457.79, \mathrm{df}=2, p<0.001)$ and the Cramer's V value of 0.75 indicated an extremely strong relationship.

\section{Nationality and region of origin}

The overall sample of trafficking victims contained 84 different nationalities of which the top ten were: Nigerian $(n=263)$, Slovakian $(n=259)$, British $(n=253)$, Romanian 


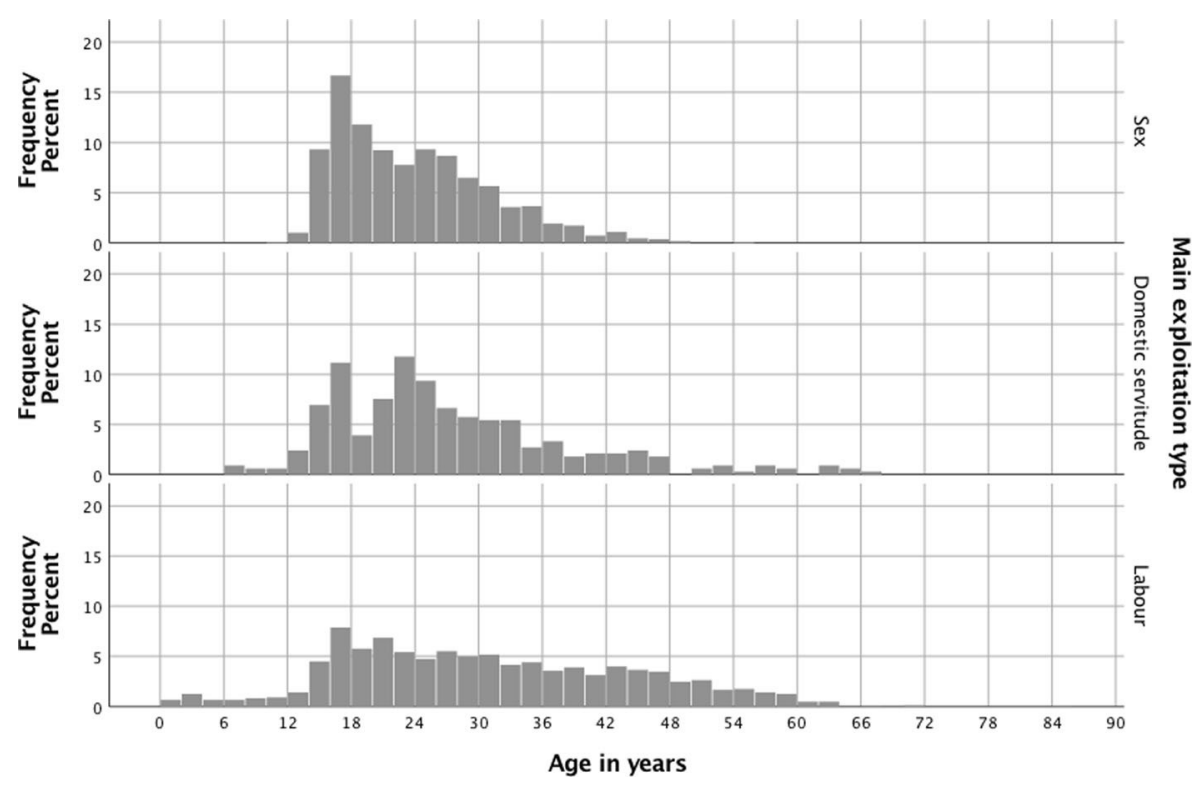

Fig. 1 Age distribution of victims split by trafficking type

$(n=249)$, Albanian $(n=187)$, Polish $(n=172)$, Vietnamese $(n=162)$, Lithuanian $(n=$ $156)$, Hungarian $(n=124)$, Czech $(n=121)$. These ten nationalities dominated, together accounting for $74.0 \%$ of the overall sample. In contrast, the remainder of the sample was diverse and fragmented, with 22 nationalities featuring just once and 54 ten times or fewer. In light of this fragmentation, it was not possible to examine differences at country-level and we looked instead at broader regions of origin: Africa; Americas (North, Central/Caribbean and South); countries in the European Economic Area (EEA); and other European countries outside the EEA (hereafter non-EEA Europe). ${ }^{8}$ There were no victims from Oceania in the sample. Our rationale for dividing Europe into EEA/non-EEA was that EEA nationals' treaty rights allow them to travel and work freely in the UK.

Of the total victims, just over half came from within the EEA $(53.7 \%, n=1413)$. As shown in Fig. 2, disaggregating the data revealed distinct patterns by trafficking type. For example, four in five labour trafficking victims came from within the EEA (79.9\%), compared with just $8.3 \%$ of those trafficked for domestic servitude. A chi-square test with Monte Carlo $p$-values showed that the differences in region of origin between trafficking types were significant $\left(\chi^{2}=1058.31, \mathrm{df}=8, p<0.001\right)$ and the Cramer's V value of 0.45 suggested a very strong relationship.

\section{Police region where victims presented}

Victims in the sample presented to the authorities in eleven different police regions: Wales, Northern Ireland, Scotland and all eight English police regions. Once again,

\footnotetext{
${ }^{8}$ In grouping countries into regions, we followed the categorisation used by the United Nations Statistics Division [79], with additional division of European countries based on European Economic Area (EEA) membership. Our sample contained 36 African countries, six American, 16 EEA and 6 non-EEA Europe.
} 


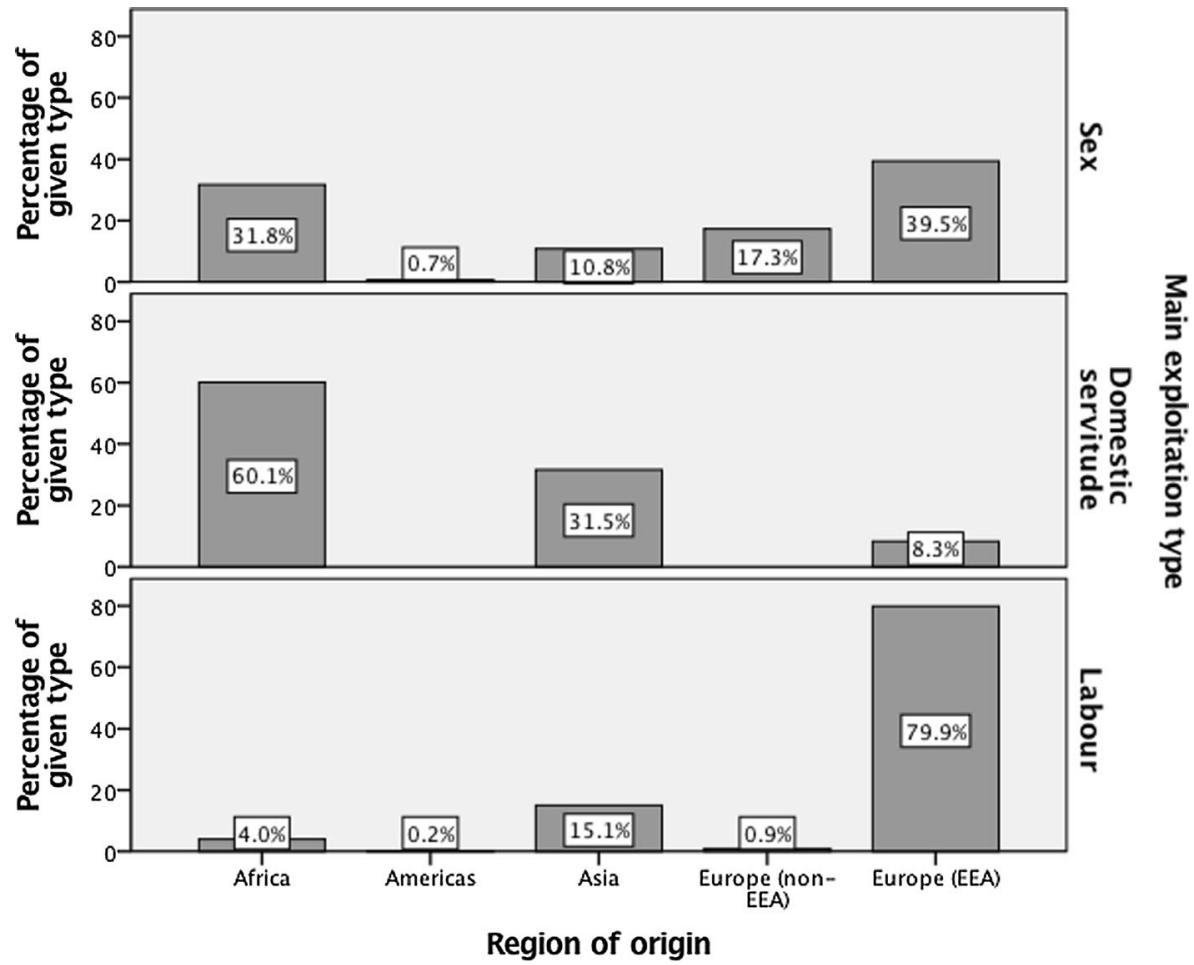

Fig. 2 Victims' region of origin split by trafficking type

disaggregating the data by trafficking type revealed important distinctions (see Fig. 3). London was the most common region overall $(25.8 \%$ of cases, $n=608)$ and also the most common for both domestic servitude (55.5\%) and sex trafficking (36.3\%)- yet it ranked just sixth for labour trafficking $(9.1 \%)$.

A chi-square test with Monte Carlo $p$-values showed that differences between trafficking types in police region of presentation were significant $\left(\chi^{2}=450.47, \mathrm{df}=\right.$ $20, p<0.001)$ and the Cramer's $\mathrm{V}$ value of 0.31 indicated that the relationship was (moderately) strong.

\section{Year of referral}

Here, we focus on cases referred into the NRM the years 2009 to 2013 inclusive. We excluded 2014 from this analysis alone as we only had partial information for that year (the source data went up to 7/10/14 only and comparatively few of the 2014 referrals had resulted in final decision by then). Figure 4 shows the year in which victims were referred into the NRM. It clearly shows how the number of victims identified as trafficked for domestic servitude remained relatively steady year-on-year over the study period. In contrast, a more obvious and sustained increase over time was evident for both sex trafficking and labour trafficking, with particularly sharp increases from 2010 to 2011 and again from 2012 to 2013.

A chi-square test showed that differences in year of referral between trafficking types were significant $\left(\chi^{2}=43.03, \mathrm{df}=8, p<0.001\right)$, although the Kendall's tau-b 


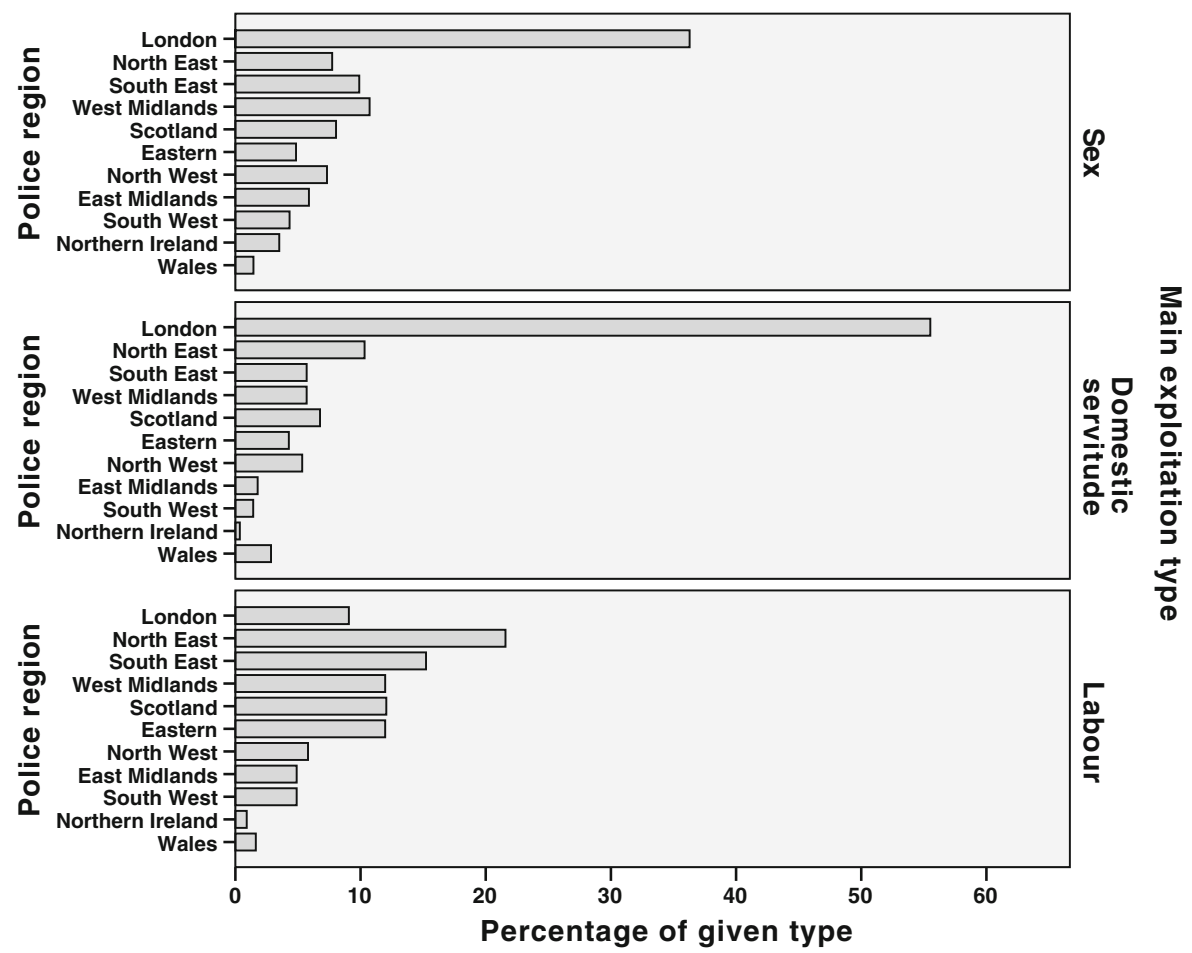

Fig. 3 Police region where victims presented split by trafficking type

value of 0.09 indicated that the relationship was (very) weak. As a check, we re-ran these statistical tests including 2014 cases and the results were very similar $\left(\chi^{2}=78.21\right.$, df $=10, \mathrm{p}<0.001$, Kendall's tau-b $=0.12$ ).

\section{Month of referral}

As shown in Fig. 5, there were some differences between trafficking types in terms of the months when victims were referred. Most notably, fewer labour trafficking victims were referred in the Spring and Summer months (March-August inclusive) than at other times of year. Although less pronounced than many of the other differences, the differences in month of referral between types were still significant $\left(\chi^{2}=65.16, \mathrm{df}=22\right.$, $p<0.001$ ), although a Cramer's $\mathrm{V}$ value of 0.11 indicated a very weak relationship.

Source of referral There were four main sources of referrals: police (plus gangmasters licensing authorities ${ }^{9}$ ); the immigration authorities; non-governmental organisations; and local authorities, including social and children's services. ${ }^{10}$ Disaggregating the data

\footnotetext{
${ }^{9}$ Police category includes 43 referrals from Gangmasters Licensing Authority (now Gangmasters and Labour Abuse Authority). All their referrals involved labour trafficking so we grouped them to avoid complete separation in the data. Differences between types cannot be explained by inclusion of GLA-referrals $(n=43)$ under category policing (742 referrals in total for labour trafficking).

${ }^{10}$ Category also included one youth offending referral and one from a prison.
} 


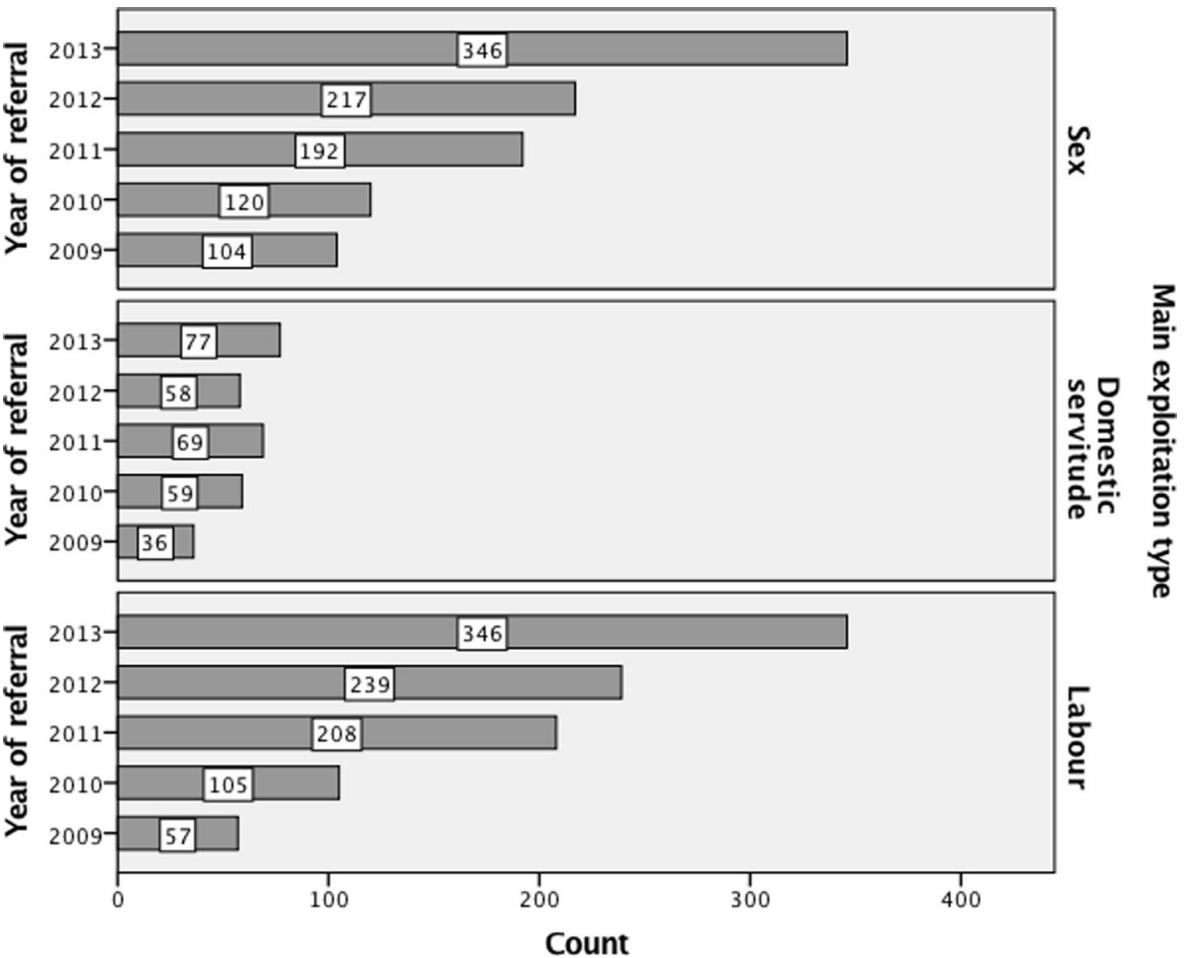

Fig. 4 Year of referral split by trafficking type

revealed clear differences between trafficking types, shown in Fig. 6. For example, the proportion of referrals from the police was markedly higher for labour trafficking than the other types. Meanwhile, a particularly large proportion of domestic servitude victims was referred by non-governmental organisations. The proportion of referrals from the immigration authorities was markedly higher for sex trafficking and domestic servitude than for labour trafficking, quite possibly linked to the higher proportion of non-EEA victims. A chi-square test showed the differences in sources of referral were significant across trafficking types $\left(\chi^{2}=403.82, \mathrm{df}=8, p<0.001\right)$ and the Cramer's V value of 0.27 showed a moderately strong association.

\section{Time to decision}

Overall, the final decision that these individuals should officially be considered trafficking victims was reached after a median of 61 days (range 0 to 1779 days $^{11}$ ). Once again, the aggregate data masked substantial differences between trafficking types: decisions were reached most quickly for labour trafficking (median 52 days), followed by sex trafficking (median 85 days). Decisions on domestic servitude took far longer (median 175 days). A Kruskal-Wallis test demonstrated that the differences in time to decision between trafficking types were significant $\left(\chi^{2}=440.69, \mathrm{df}=2, p<0.001\right)$,

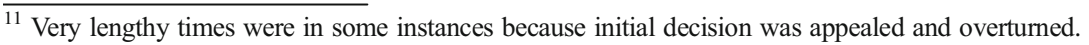




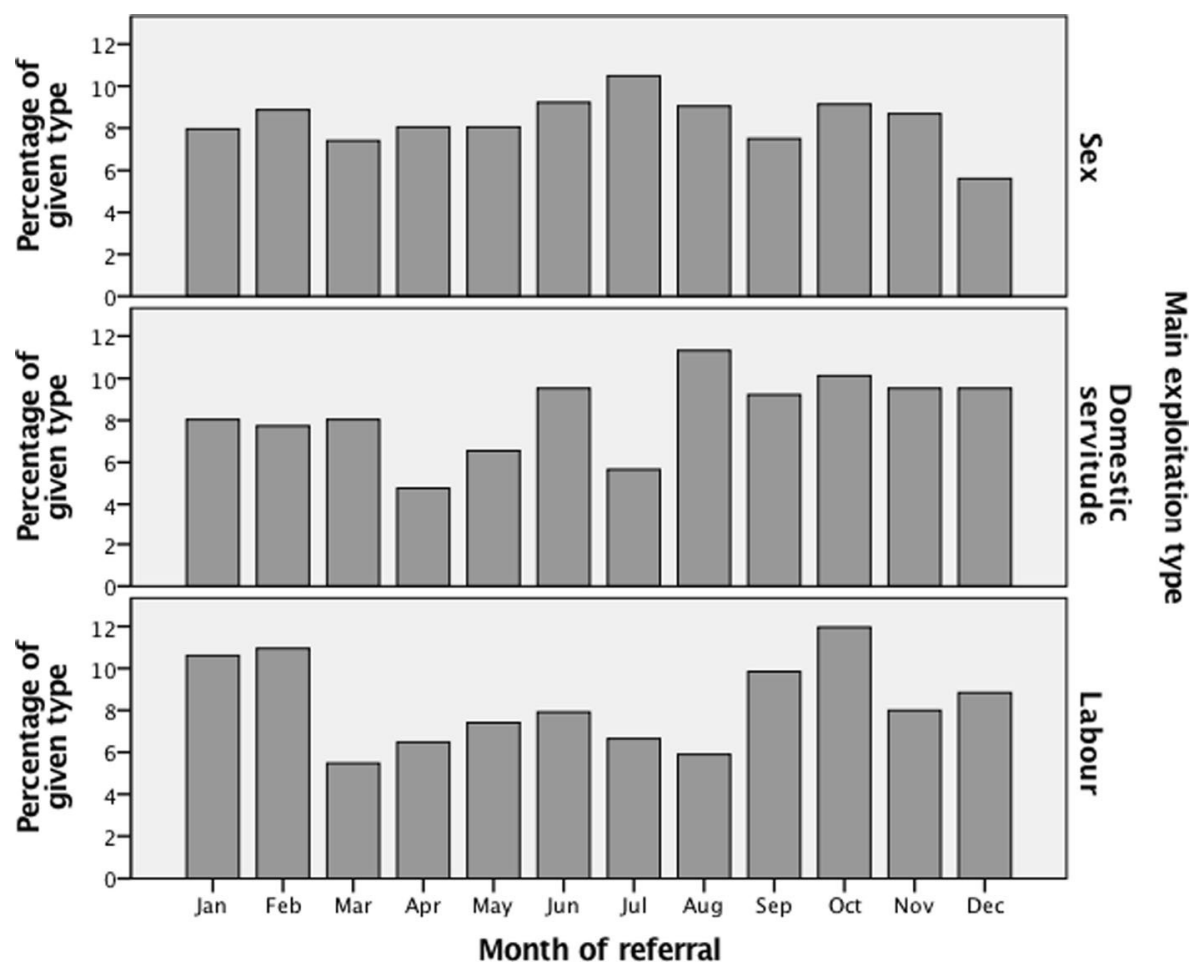

Fig. 5 Month of referral split by trafficking type

although the epsilon squared value of 0.17 indicated a fairly weak relationship. Differences between trafficking types in time to decision might be at least partially related to differences in NCA and UKVI procedures (the NCA deal with EEA cases only, which a higher proportion of labour trafficking cases were).

\section{Identification of predictors of trafficking type}

The exploratory data analysis gave a useful overview of our full dataset, helping tease out and patterns and possible relationships. Next, we used multinomial logistic regression to build a model to control for possible relationships between variables and investigate the relative power of the different variables in distinguishing between different trafficking types. As explained previously, the regression analysis was necessarily limited to victims from Africa, Asia or the EEA.

We built the model iteratively, using a main effects modelling strategy. Following the principle of parsimony, we culled our model only to include significant predictors (at the traditional $p<0.05$ criterion of statistical significance). All variables described in the exploratory data analysis were included, except for 'year of referral' (did not meet $p$ threshold) and 'nationality' (due to data constraints, the aggregated 'region of origin' was used instead). All variables used in the model contributed significantly to model fit, tested using Likelihood Ratio Tests. We ruled out multicollinearity between variables using collinearity diagnostics (results available on request). 


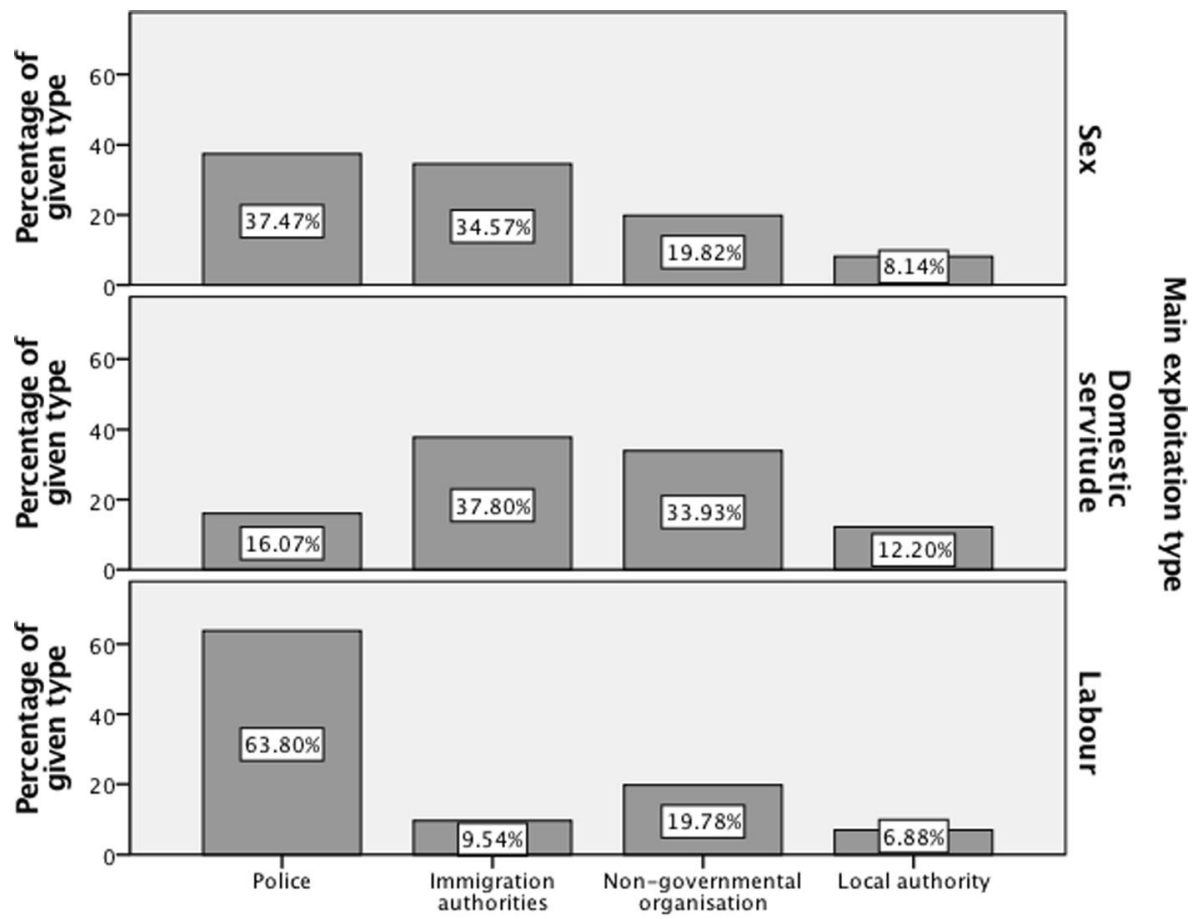

Source of referral

Fig. 6 Source of referral split by trafficking type

Our final model contained 2121 cases: 1061 victims of labour trafficking, 788 of sex trafficking victims and 272 of trafficking for domestic servitude. Descriptive statistics are available in Appendix 1. Addition of the predictors to a model that contained only the intercept significantly improved the fit $\left(-2 \log\right.$ Likelihood $=2190.995, \chi^{2}=1956.621, \mathrm{df}=$ $58, p<0.001$, Nagelkerke $\mathrm{R}^{2}=0.702$ ). The model correctly predicted exploitation type for $78.5 \%$ of victims, although it was markedly more accurate at predicting labour trafficking ( $84.4 \%$ correct) and sex trafficking ( $86.8 \%$ correct) than domestic servitude (30.9\% correct). Collectively, the likelihood-ratio test, pseudo $\mathrm{R}^{2}$ and percentage of cases correctly classified suggested the model had a good ability to discriminate between trafficking types.

To understand the extent and direction of changes that each independent variable (or category thereof) predicts in the dependent variable (trafficking type), we examine the exponent of the B co-efficient $(\operatorname{Exp}(B))$. Figure 7 provides a forest plot (on a log-2 scale) showing all statistically significant results for the $\operatorname{Exp}(\mathrm{B})$ values, otherwise known as relative risk ratios, and associated $95 \%$ confidence intervals (CIs). It covers the three type-wise comparisons in the model: domestic servitude versus labour trafficking; sex trafficking versus labour trafficking; and domestic servitude versus sex trafficking. Simply put, the values to the left of the dashed line (representing the null hypothesis of no effect given by $\operatorname{Exp}(0)=1.00)$ mean a case with the given characteristic is less likely to be the specified trafficking type than the comparison type, whereas the reverse is true of values to the right. In the appendices, we provide full parameter estimates for the multinomial logistic regression (Appendix 2) and a full forest plot of $\operatorname{Exp}(\mathrm{B})$ values that also includes non-significant results (Appendix 3). 


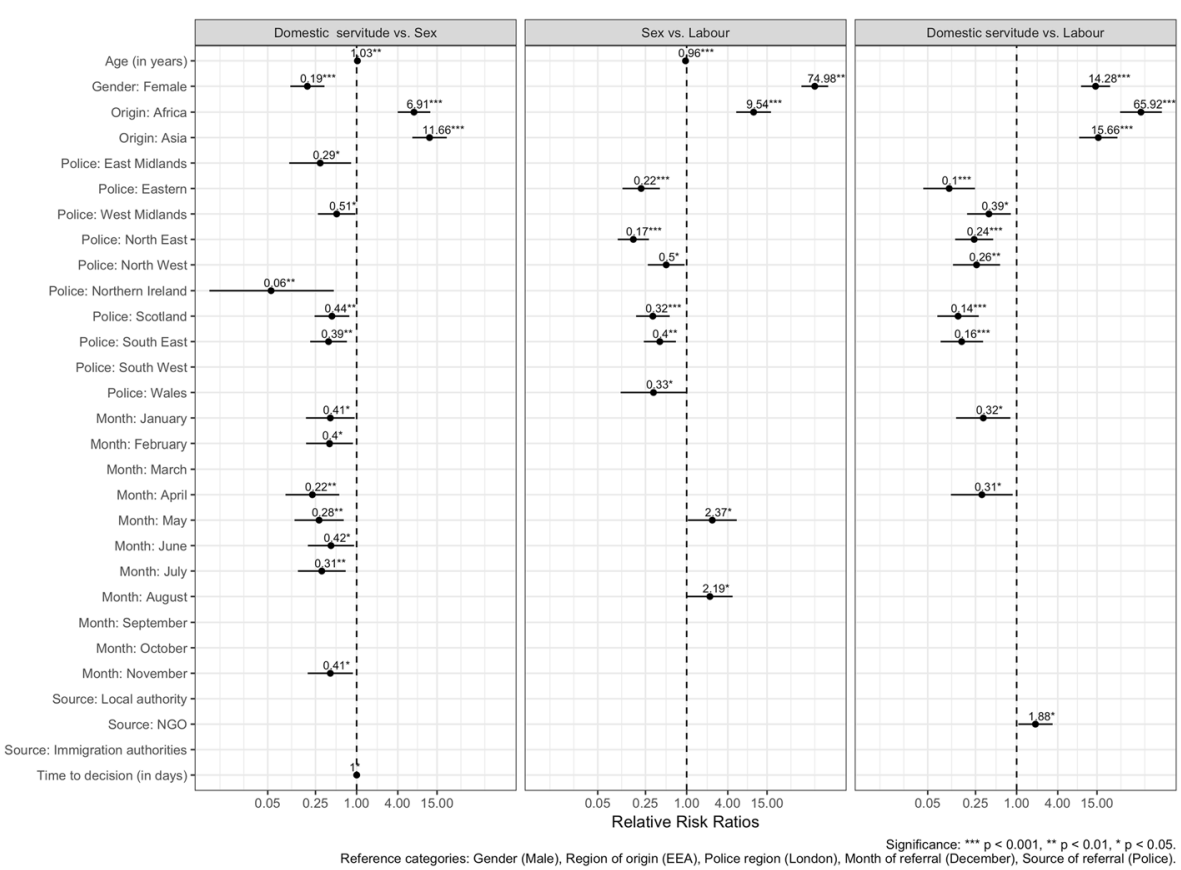

Fig. 7 Forest plot of relative risk ratios and associated $95 \%$ confidence intervals (statistically significant results only), done to a $\log 2$ scale

Generally speaking the results reflect similar trends to those outlined in the bivariate analysis, but several interesting findings merit closer examination. While all the variables have predictive utility at the overall model-level, the significance, direction and strength of effect often varied considerably at the level of pair-wise comparisons between trafficking types.

The most pronounced results were around gender. All other variables held constant (we will not keep repeating this caveat but it is important to bear in mind throughout the results), being female means someone is 75 times more likely to have been trafficked for sex than labour. The same trend is evident, although somewhat less pronounced, when comparing domestic servitude and labour: being female means someone is 14 times more likely to have been trafficked for domestic servitude than for labour. The influence of gender is far less keenly felt when comparing domestic servitude and sex: being female means someone is 0.19 times as likely (i.e. somewhat less likely) to have been trafficked for domestic servitude than sex.

Region of origin had clear predictive utility too. Most notably, coming from Africa as compared to the EEA meant someone was 65.9 times more likely to have been trafficked for domestic servitude than labour, 9.5 more likely to have been trafficked for sex than labour and 6.9 times more likely to have been trafficked for domestic servitude than sex. Meanwhile, coming from Asia as compared to the EEA meant someone was 15.7 times more likely to have been trafficked for domestic servitude than labour and 11.7 times more likely to have been trafficked for domestic servitude than sex.

Some variables only predict trafficking type in certain pair-wise comparisons. A good example is age, which was not significant when comparing domestic servitude and labour. For the other two comparisons, the predictive power accumulates as wider 
age gaps are considered. For example, for a one-year increase in age, the relative risk of someone having been trafficked for sex rather than labour decreases by 3.7\%. For a five-year increase in age, however, the relative risk decreases by $17.3 \%$. Similarly, for a one-year increase in age, the relative risk of someone having been trafficked for domestic servitude rather than sex increases by $2.6 \%$, whereas for a five-year increase in age, the increase in relative risk is $13.3 \%$.

There were numerous police regions of presentation in which a victim was comparatively less likely than one in London to have been trafficked for domestic servitude than labour, sex than labour and/or for domestic servitude than sex. The South East and Scotland had significant results for all three pair-wise comparisons, indicating that the relative composition of the trafficking identified in these regions particularly diverged from that in London. Overall, the regional patterning varied in significance and strength many of the differences were fairly subtle: relative risk ratios ranged from 0.06 to 0.51 (i.e. around half as likely).

Seasonal patterning was also complex and typically subtle. There were eight months in which, compared to December, a victim referred into the system was more or less likely to have been trafficked for one form of exploitation than another. While many of the differences were fairly subtle, some seasonal results were comparatively more pronounced: people referred into the system in May and August (compared to December) were respectively 2.4 and 2.2 times more likely to have been trafficked for labour than for sex.

The time to reach a decision on a victim's trafficking status was only significant in comparing domestic servitude and sex (but this result in itself shows type-specific differences independent of decision-making authority). As with age differences, the effects were most pronounced when considering longer intervals: the relative risk of having been trafficked for domestic servitude rather than sex increases by $0.1 \%$ for a one-day increase in time, $20.0 \%$ for a six-month increase and $43.9 \%$ for a one-year increase. In other words, considerably longer times to decision are more strongly predictive of someone having been trafficked for domestic servitude than sex.

Finally, source of referral was only significant for one category and one pair-wise comparison of trafficking types: referral from an NGO as compared to the police increases the relative risk of having been trafficked for domestic servitude rather than labour by $88.4 \%$.

A key strength of the multinomial logistic regression is that it demonstrates that the individual independent variables have predictive power over and above the other variables in the model. Hence, for example, someone who is older, male, comes from the EEA and identified in various police regions outside of London is even more likely to have been trafficked for labour rather than sex than someone with just one of these characteristics.

\section{Discussion}

As highlighted in the introduction, human trafficking is a broad conceptual umbrella that encompasses various different forms of exploitation. While there are empirical and theoretical grounds to expect differences between key trafficking types, there is very little robust quantitative research on this topic. Using nationwide data from the UK's 
National Referral Mechanism, we addressed this knowledge gap by examining at scale similarities and differences between those trafficked for sexual exploitation, domestic servitude and labour exploitation.

We hypothesised that differences would exist between the trafficking types in terms of victims' socio-demographic characteristics, trafficking experiences and official responses to them. Our results clearly support this hypothesis, with significant differences identified through both bivariate and multivariate analyses. These distinctions were not only statistically significant but also often substantial in magnitude. The most obvious example was gender: boys and men were substantially more likely to have been trafficked for labour than for sex or domestic servitude. This result echo gendered patterns in trafficking frequently reported by various national agencies and transnational bodies (e.g. [53, 78]). Using inferential statistics and controlling for the effects of other variables increases confidence in the validity of our findings, providing a clear advantage over purely descriptive comparison of trafficking types. Other differences were more complex and there was much subtle variation in pair-wise comparisons in terms of significance, direction and size of effect for different variables and their sub-categories. All three pair-wise comparisons yielded significant results, indicating that genuine differences exist between the trafficking types. Overall, our study demonstrates the value of using individual-level data and a quantitative approach in disentangling some of the complex relationships around human trafficking and its various forms. While we identified significant differences at group-level, considerable within-group variation serves as an important reminder that the different trafficking types are not homogeneous. Moreover, victims who diverge from norms and stereotypes (e.g. men trafficked for sex) may be less likely to be identified and risk being overlooked in policy and practice.

Our study also has some important limitations. As explained previously, our data may well be subject to various biases in the identification of victims, collection of data and processing of cases. Additionally, both trafficking and counter-trafficking are dynamic phenomena and the landscape has likely shifted since our study period. Certainly, the number of referrals into the NRM has increased steeply year-on-year $[18,53]$. There is also greater recognition that UK nationals can be trafficked domestically, be it for child sexual exploitation (e.g. $[8,11]$ ), 'county lines' related criminal exploitation (drug distribution and sales) (e.g. [18, 57]) or other forms of labour trafficking (e.g. [13]). Political prioritisation of 'modern slavery' and multi-million pound investment in improving law enforcement responses - after a damning independent review [41]- have likely affected local awareness, understanding and enforcement activity.

Given the constraints of the original data source, we explored the discriminatory power of a relatively small number of variables. All variables that predicted trafficking type are routinely collected and many have obvious potential for targeted policy and practice. Of course, there are almost certainly numerous other factors distinguishing between trafficking types. Many variables of potential research interest did not feature in the original data, or were captured but not useable due to missing data. In building a more evidence-informed approach, it would be useful to establish how victims of different trafficking types compare in terms of duration of exploitation (which are anecdotally said to differ, [62]), means of transportation, control mechanisms experienced, pathways in and out of trafficking and health impacts and post-trafficking support needs (building on [58, 59]). 
Using large samples better to understand different trafficking types has considerable potential for informing the design, delivery and prioritisation of interventions. Primary research, which is often under-funded, has much to offer here (see [82]). Yet, there is also considerable scope to optimise data already collected by official agencies, NGOs and others [19]. More expansive scientific analysis and robust data-driven policy require data collection to become more detailed and systematic. We appreciate, of course, that some information will invariably be missing at times and the competing demands of what is maximally informative, viable and proportionate must be balanced. In the UK, the on-going NRM reforms offer a valuable opportunity to enhance the collection of nuanced information about victims and their experiences, vulnerabilities and points of resilience pre-, during- and post-trafficking.

Explanations of the drivers of trafficking (e.g. push and pull factors) are often global (both in geographic and thematic terms) and far less attention is paid to local environment and the contingencies of specific trafficking types [49]. Yet, research into numerous other crimes emphasises that context is vital [34]. Since human trafficking is typically a for-profit activity, there are likely dependencies on the structure and regulation of relevant markets and activities, including migration and low-paid work more generally. Our results provide some indication that opportunity theories of crime apply to human trafficking too, meaning that traffickers operate pragmatically and rationally (not to be confused with legally or morally) (see also [16]). Indeed, many of our findings could be explained in terms of minimising effort and risk, maximising profit and responding to market demands and operating conditions and constraints. For example, the most common demographic for sex trafficking (young women) would seem to mirror consumer preference in the wider sex industry. The comparatively flatter age distribution for domestic servitude and labour trafficking would seem to reflect a lower premium on youth (with some exceptions, e.g. children are a useful asset for benefit fraud and certain other criminal exploitation). The clear predominance of EEA nationals among labour trafficking victims likely reflects the relative ease with which they can be inserted into the licit labour market. In contrast, migration status and right to work may be less relevant when dealing with the more hidden and informalised industries of sex and domestic work.

We also found spatial patterning in terms of police regions where victims presented and thus were likely, although not necessarily, exploited. To a lesser extent, there was also temporal patterning. Spatial differences may reflect differences in the type of work available locally, the concentration of diaspora communities and/or awareness and enforcement activity, among other factors. Temporal differences might reflect factors such as seasonal patterns in various industries (e.g. agriculture/food processing, [23]), the relative visibility of different victim groups at different times of year and/or enforcement activity. Although our results cannot offer definitive answers, they raise important questions about the opportunity structures of trafficking activity and highlight the need for further enquiry into the temporal and spatial distribution of trafficking, an under-researched topic $[19,46]$. There is obvious potential to extend environmental criminology's ideas and techniques to human trafficking, whereby results could inform more finely-targeted interventions aimed at high-risk times and places.

Other differences identified here could also usefully be explored further in future research. For example, differences in referrals from NGOs relative to police for labour 
trafficking and domestic servitude victims might reflect variation in their visibility, their willingness to engage with certain agencies and/or organisational priorities. Similarly, the comparatively long times to decision in domestic servitude cases may reflect particular complexities of this trafficking type and/or responses to it.

Unlike the UK, various other countries combine data on trafficking for domestic servitude and other labour [12] so the two are often aggregated in international research and reporting (e.g. [29, 78]). The significant differences identified here provide a clear argument for separating out domestic servitude in analysis and intervention. Despite the breadth of the labour trafficking category, we found clear distinctions between it and the other types. In future, it would be useful to delve further into intra-type variation, looking for example at how different forms of labour trafficking compare (although we are mindful of our on-going research showing many labour trafficking victims are exploited across various different industries, [17, 19]).

We have presented an initial study of differences between trafficking types based on the UK context alone. In future, it would be useful to replicate the study in other countries. There may well be interactions with other factors that vary by country, such as geographical positioning, migration policies and flows, legislative landscapes, labour market demands, social norms and counter-trafficking enforcement activity. An exciting development worth mentioning here is the Counter-Trafficking Data Collaborative (CTDC) (www.ctdatacollaborative.org), an open-access hub with thousands of individual-level, anonymised entries for victims of human trafficking identified worldwide. This initiative and other on-going attempts to create accessible and comparable individual-level datasets on trafficking victims or incidents (we are not aware of any that focus on offenders, although they would be helpful too) could help break down data access-related barriers to quantitative research on human trafficking and facilitate a more vibrant research field.

\section{Conclusion}

Interest and investment in tackling human trafficking have grown dramatically over the past decades yet the bulk of attention has focused on sex trafficking. Drawing on an empirically-rich, individual-level dataset of thousands of trafficking victims identified in the UK, we found important and often nuanced distinctions between those trafficked for sex, labour and domestic servitude. While the results are by no means definitive, the study underscores the value of a detailed and disaggregated approach to monitoring, analysis, research and intervention. Replicating the research elsewhere would help understand whether and how differences in trafficking types vary according to local context. With better data, there would also be scope to examine how trafficking types compare on other dimensions. A much more nuanced understanding of human trafficking would yield important insights for explanation and intervention. Overall, the work shows that human trafficking is a diverse and complex phenomenon, improved data are sorely needed and a one-size-fits-all approach developed primarily to combat the trafficking of women and girls for sexual exploitation is insufficient. 
grateful to the National Crime Agency for facilitating our research, providing crucial data access and answering questions that arose during the analysis. Finally, we thank our editors, anonymous reviewers and our colleague Patricio Estevez-Soto for all their insightful comments and advice.

\section{Appendix 1}

Table 2 Variable coding and descriptive statistics for the logistic regression $(n=2121)$

\begin{tabular}{|c|c|c|c|c|c|}
\hline \multirow[t]{2}{*}{ Variable } & \multirow[t]{2}{*}{ Category } & \multicolumn{3}{|c|}{ Ordinal variables } & \multirow{2}{*}{$\begin{array}{l}\text { Categorical } \\
\text { variables } \\
\%\end{array}$} \\
\hline & & Mean & SD & Range & \\
\hline Age (years) & - & 27.33 & 11.96 & $0.25-84.5$ & \\
\hline \multirow[t]{2}{*}{ Gender } & Female & & & & $58.6 \%$ \\
\hline & Male & & & & $41.4 \%$ \\
\hline \multirow[t]{3}{*}{ Region of origin } & Africa & & & & $22.7 \%$ \\
\hline & Asia & & & & $15.8 \%$ \\
\hline & EEA & & & & $61.5 \%$ \\
\hline \multirow[t]{11}{*}{ Police region } & East Midlands & & & & $5.4 \%$ \\
\hline & Eastern & & & & $8.8 \%$ \\
\hline & West Midlands & & & & $11.4 \%$ \\
\hline & North East & & & & $15.3 \%$ \\
\hline & North West & & & & $6.5 \%$ \\
\hline & Northern Ireland & & & & $2.0 \%$ \\
\hline & Scotland & & & & $10.2 \%$ \\
\hline & South East & & & & $12.5 \%$ \\
\hline & South West & & & & $3.5 \%$ \\
\hline & Wales & & & & $1.9 \%$ \\
\hline & London & & & & $22.5 \%$ \\
\hline \multirow[t]{12}{*}{ Month of referral } & January & & & & $9.1 \%$ \\
\hline & February & & & & $9.4 \%$ \\
\hline & March & & & & $6.4 \%$ \\
\hline & April & & & & $6.5 \%$ \\
\hline & May & & & & $7.0 \%$ \\
\hline & June & & & & $8.5 \%$ \\
\hline & July & & & & $8.7 \%$ \\
\hline & August & & & & $8.4 \%$ \\
\hline & September & & & & $9.3 \%$ \\
\hline & October & & & & $10.6 \%$ \\
\hline & November & & & & $8.6 \%$ \\
\hline & December & & & & $7.4 \%$ \\
\hline \multirow[t]{4}{*}{ Source of referral } & Local authority & & & & $8.9 \%$ \\
\hline & NGO & & & & $19.2 \%$ \\
\hline & Immigration authorities & & & & $17.4 \%$ \\
\hline & Police & & & & $54.5 \%$ \\
\hline Time to decision (days) & - & 125.83 & 160.88 & $5-1579$ & \\
\hline
\end{tabular}




\section{Appendix 2}

Table 3 Parameter estimates

\begin{tabular}{|c|c|c|c|c|}
\hline \multirow[t]{2}{*}{ Variable } & & \multirow{2}{*}{$\begin{array}{l}\text { Sex vs. labour } \\
\text { B(SE) }\end{array}$} & \multirow{2}{*}{$\begin{array}{l}\text { Domestic servitude vs. } \\
\text { labour } \\
\mathrm{B}(\mathrm{SE})\end{array}$} & \multirow{2}{*}{$\begin{array}{l}\text { Domestic } \\
\text { servitude vs. sex } \\
\mathrm{B}(\mathrm{SE})\end{array}$} \\
\hline & & & & \\
\hline Intercept & & $-2.442(0.458) * * *$ & $-3.255(0.526)^{* * *}$ & $-0.813(2.509) * * *$ \\
\hline Age (in years) & & $-0.038(0.008) * * *$ & $-0.013(0.010), \mathrm{ns}$ & $0.025(0.009)^{*}$ \\
\hline $\begin{array}{l}\text { Gender (referent } \\
\text { group male) }\end{array}$ & Female & $4.317(0.231)^{* * *}$ & $2.659(0.250)^{* * *}$ & $-1.658(0.292) * * *$ \\
\hline \multirow{2}{*}{$\begin{array}{l}\text { Region of origin } \\
\text { (referent group } \\
\text { EEA) }\end{array}$} & Africa & $2.256(0.299)^{* * *}$ & $4.188(0.360)^{* * *}$ & $1.932(0.281)^{* * *}$ \\
\hline & Asia & $0.295(0.265), \mathrm{ns}$ & $2.751(0.329) * * *$ & $2.456(0.296)^{* * *}$ \\
\hline \multirow{10}{*}{$\begin{array}{l}\text { Police region where } \\
\text { presented in UK } \\
\text { (referent group } \\
\text { London) }\end{array}$} & East Midlands & $0.547(0.393), \mathrm{ns}$ & $-0.682(0.576), \mathrm{ns}$ & $-1.229(0.533)^{*}$ \\
\hline & Eastern & $-1.534(0.323) * * *$ & $-2.272(0.444)^{* * *}$ & $-0.738(0.377), \mathrm{ns}$ \\
\hline & West Midlands & $-0.261(0.281), \mathrm{ns}$ & $-0.934(0.377)^{*}$ & $-0.673(0.323)^{*}$ \\
\hline & North East & $-1.798(0.269) * * *$ & $-1.431(0.327)^{* * *}$ & $0.366(0.288), \mathrm{ns}$ \\
\hline & North West & $-0.689(0.316)^{*}$ & $-1.350(0.405)^{* *}$ & $-0.661(0.349), \mathrm{ns}$ \\
\hline & Northern Ireland & $0.725(0.534), \mathrm{ns}$ & $-2.153(1.111), \mathrm{ns}$ & $-2.877(1.075)^{* *}$ \\
\hline & Scotland & $-1.138(0.290)^{* * *}$ & $-1.971(0.355)^{* * *}$ & $-0.833(0.299)^{* *}$ \\
\hline & South East & $-0.904(0.276)^{* *}$ & $-1.850(0.367)^{* * *}$ & $-0.946(0.316)^{* *}$ \\
\hline & South West & $0.160(0.424), \mathrm{ns}$ & $-0.728(0.655), \mathrm{ns}$ & $-0.888(0.584), \mathrm{ns}$ \\
\hline & Wales & $-1.119(0.567)^{*}$ & $-1.059(0.642), \mathrm{ns}$ & $0.061(0.488), \mathrm{ns}$ \\
\hline \multirow{11}{*}{$\begin{array}{l}\text { Month of referral } \\
\text { (referent group } \\
\text { December) }\end{array}$} & January & $-0.236(0.376), \mathrm{ns}$ & $-1.124(0.466)^{*}$ & $-0.888(0.419)^{*}$ \\
\hline & February & $0.207(0.385), \mathrm{ns}$ & $-0.707(0.461), \mathrm{ns}$ & $-0.913(0.403)^{*}$ \\
\hline & March & $0.775(0.406), \mathrm{ns}$ & $0.260(0.481), \mathrm{ns}$ & $-0.515(0.408), \mathrm{ns}$ \\
\hline & April & $0.319(0.400), \mathrm{ns}$ & $-1.173(0.530)^{*}$ & $-1.492(0.462)^{* *}$ \\
\hline & May & $0.864(0.421)^{*}$ & $-0.402(0.504), \mathrm{ns}$ & $-1.265(0.424)^{* *}$ \\
\hline & June & $0.513(0.395), \mathrm{ns}$ & $-0.353(0.463), \mathrm{ns}$ & $-0.866(0.399)^{*}$ \\
\hline & July & $0.544(0.389), \mathrm{ns}$ & $-0.630(0.476), \mathrm{ns}$ & $-1.174(0.411)^{* *}$ \\
\hline & August & $0.784(0.390)^{*}$ & $0.092(0.444), \mathrm{ns}$ & $-0.692(0.373), \mathrm{ns}$ \\
\hline & September & $0.379(0.403), \mathrm{ns}$ & $-0.386(0.468), \mathrm{ns}$ & $-0.765(0.399), \mathrm{ns}$ \\
\hline & October & $0.107(0.381), \mathrm{ns}$ & $-0.095(0.448), \mathrm{ns}$ & $-0.202(0.394), \mathrm{ns}$ \\
\hline & November & $0.612(0.397), \mathrm{ns}$ & $-0.276(0.456), \mathrm{ns}$ & $-0.887(0.389)^{*}$ \\
\hline \multirow{3}{*}{$\begin{array}{l}\text { Source of referral } \\
\text { (referent group } \\
\text { police) }\end{array}$} & Local authority & $-0.230(0.265), \mathrm{ns}$ & $0.251(0.333), \mathrm{ns}$ & $0.481(0.294), \mathrm{ns}$ \\
\hline & $\begin{array}{l}\text { Non-governmental } \\
\text { organisation }\end{array}$ & $0.332(0.235), \mathrm{ns}$ & $0.634(0.295)^{*}$ & $0.302(0.246), \mathrm{ns}$ \\
\hline & $\begin{array}{l}\text { Immigration } \\
\text { authorities }\end{array}$ & $-0.017(0.270), \mathrm{ns}$ & $-0.193(0.311), \mathrm{ns}$ & $-0.176(0.245), \mathrm{ns}$ \\
\hline $\begin{array}{l}\text { Time to } \\
\text { decision (days) }\end{array}$ & & $-3.255(0.526), \mathrm{ns}$ & $0.001(0.001), \mathrm{ns}$ & $0.001(0.000)^{*}$ \\
\hline
\end{tabular}

$n s$, non significant

$* \mathrm{p}<0.05, * * \mathrm{p}<0.01, * * * p<0.001$ 


\section{Appendix 3}

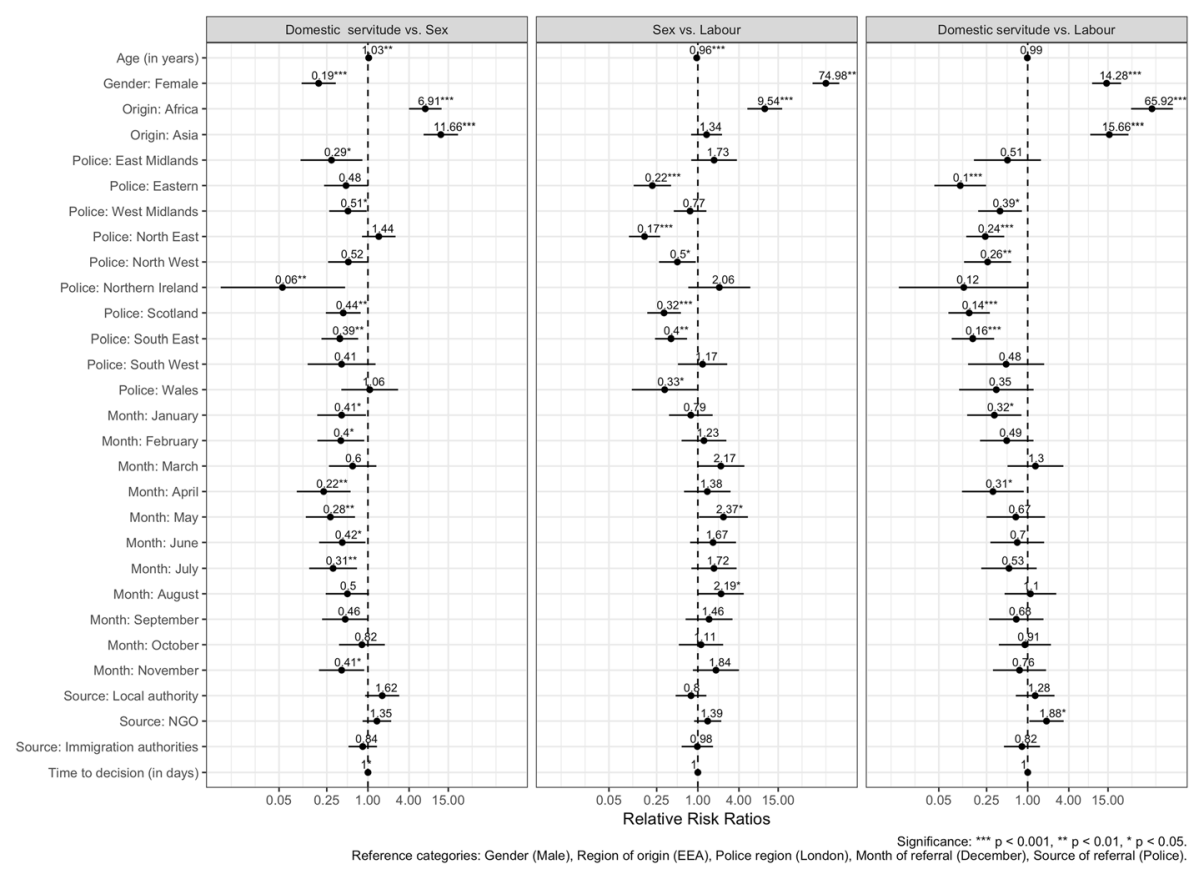

Fig. 8 Forest plot of all relative risk ratios and associated $95 \%$ confidence intervals (includes non-significant results), done to a $\log 2$ scale

Open Access This article is distributed under the terms of the Creative Commons Attribution 4.0 International License (http://creativecommons.org/licenses/by/4.0/), which permits unrestricted use, distribution, and reproduction in any medium, provided you give appropriate credit to the original author(s) and the source, provide a link to the Creative Commons license, and indicate if changes were made.

\section{References}

1. Andrees, B., \& van der Linden, M. N. J. (2005). Designing trafficking research from a labour market perspective: The ILO Experience1. International Migration, 43(1-2), 55-73.

2. Antal, I., \& Laszlo, E. (2015) The Situation of Human Trafficking for Labour Exploitation in Romania. In 2nd International Multidisciplinary Scientific Conference on Social Sciences and Arts, Albena,: SGEM.

3. APPG (2018). Behind Closed Doors: Organised sexual exploitation in England and Wales. London: All Party Parliamentary Group (APPG) on Prostitution and the Global Sex Trade.

4. Barrick, K., Lattimore, P. K., Pitts, W. J., \& Zhang, S. X. (2014). When farmworkers and advocates see trafficking but law enforcement does not: Challenges in identifying labor trafficking in North Carolina. Crime, Law and Social Change, 61(2), 205-214.

5. Bokhari, F. (2008). Falling through the gaps: Safeguarding children trafficked into the UK. Children \& Society, 22(3), 201-211.

6. Brantingham, P. J., \& Brantingham, P. L. (1984). Patterns in crime. New York: Macmillan. 
7. Brantingham, P. J., \& Brantingham, P. L. (1993). Environment, routine and situation: Toward a pattern theory of crime. Advances in Criminological Theory, 5, 259-294.

8. Brayley, H., \& Cockbain, E. (2014). British children can be trafficked too: Towards an inclusive definition of internal child sex trafficking. Child Abuse Review, 23(3), 171-184. https://doi.org/10.1002 /car.2307.

9. Brooks-Gordon, B., \& Sanders, T. (2018). Banning sex work advertising online will put sex workers in danger. The Independent. Retrieved from https://www.independent.co.uk/voices/sex-workonlineadvertising-ban-will-put-sex-workers-in-danger-a8436101.html. Accessed 5/3/19

10. Brunovskis, A., \& Surtees, R. (this issue). Identifying trafficked migrants and refugees along the Balkan route. Exploring boundaries of exploitation, vulnerability and risk. Crime, Law and Social Change.

11. Cockbain, E. (2018). Offender and Victim Networks in Human Trafficking. Abingdon. Routledge.

12. Cockbain, E., Bowers, K., \& Dimitrova, G. (2018). Human trafficking for labour exploitation: The results of a two-phase systematic review mapping the European evidence base and synthesising key scientific research evidence. Journal of Experimental Criminology, 14(3), 319-360. https://doi.org/10.1007 /s11292-017-9321-3.

13. Cockbain, E., \& Brayley-Morris, H. (2017). Human trafficking and labour exploitation in the casual construction industry: An analysis of three major investigations in the United Kingdom involving Irish Traveller offending groups. Policing: A Journal Of Policy And Practice.

14. Cockbain, E., Ashby, M., \& Brayley, H. (2015). Immaterial boys? A large-scale exploration of genderbased differences in child sexual exploitation service users. Sexual abuse: a journal of research and treatment, 29(7), 658-684.

15. Cockbain, E., Ashby, M., \& Brayley-Morris, H. (2016). Children, gender and sexual exploitation: A quantitative analysis of adminstrative data. SAGE Research Methods Cases, 2, 1-17. https://doi. org/10.4135/9781473993341.

16. Cockbain, E., \& Wortley, R. (2015). Everyday atrocities: Does internal (domestic) sex trafficking of British children satisfy the expectations of opportunity theories of crime? Crime Science, 4(1), 1-12.

17. Cockbain, E., \& Bowers, K. (2018). Applying data science techniques to human trafficking research. Paper presented at the United Nations on Drugs and Crime (UNODC) 4th International Conference on Governance, Crime and Justice Statistics, Lima, Peru.

18. Cockbain, E., \& Olver, K. (2019). Child trafficking: characteristics, complexities and challenges. In I. Bryce, W. Petherick, \& Y. Robinson (Eds.), Child Abuse and Neglect: Forensic Issues in Evidence, Impact and Management (pp. 95-116). New York: Elsevier

19. Cockbain, E., Bowers, K., \& Vernon, L. (2019). Using law enforcement data in trafficking research. In J. Winterdyk \& J. Jones (Eds.), The Palgrave International Handbook of Human Trafficking. Basingstoke: Palgrave Macmillan.

20. Cohen, L. E., \& Felson, M. (1979). Social change and crime rate trends: A routine activity approach. American Sociological Review, 44, 588-608.

21. Cornish, D. B., \& Clarke, R. V. (1986). The reasoning criminal: Rational choice perspectives on offending. New York: Springer.

22. Council of Europe (2005). Council of Europe Convention on Action against Trafficking in Human Beings and its Explanatory Report. In C. o. Europe (Ed.), Treaty Series No. 197. Strasbourg: Council of Europe.

23. Davies, J. (2018). From severe to routine labour exploitation: The case of migrant workers in the UK food industry. Criminology \& Criminal Justice, 1748895818762264.

24. Doezema, J. (1999). Loose women or lost women? The re-emergence of the myth of white slavery in contemporary discourses of trafficking in women. [journal article]. Gender Issues, 18(1), 23-50. https://doi.org/10.1007/s12147-999-0021-9.

25. Doezema, J. (2013). Sex slaves and discourse masters: The construction of trafficking. London: Zed Books Ltd..

26. Efrat, A. (2016). Global efforts against human trafficking: The misguided conflation of sex, labor. and organ trafficking. International Studies Perspectives, 17(1), 34-54.

27. European Commission (2012). The EU Strategy towards the Eradication of Trafficking in Human Beings 2012-2016. Brussels: European Commission.

28. European Parliament (2011). Directive 2011/36/EU of the European Parliament and of the Council on preventing and combatting trafficking in human beings and protecting its victims. Strasbourg: European Parliament.

29. Eurostat (2015). Trafficking in human beings. 2015 edition. Luxembourg: Publications Office of the European Union. 
30. Everson, S. (2003). Repeat victimisation and prolific offending: Chance or choice? International Journal of Police Science \& Management, 5(3), 180-194.

31. Farrell, A. (2014). Environmental and institutional influences on police agency responses to human trafficking. Police Quarterly, 17(1), 3-29.

32. Farrell, A., Owens, C., \& McDevitt, J. (2014). New laws but few cases: Understanding the challenges to the investigation and prosecution of human trafficking cases. Crime, Law and Social Change, 61(2), 139-168.

33. Farrell, G., \& Pease, K. (2001). Why repeat victimization matters. In G. Farrell, \& K. Pease (Eds.), Repeat Victimization (12 ed., pp. 1-4, Crime Prevention Studies). Monsey: Criminal Justice Press.

34. Felson, M., \& Eckert, M. (2015). Crime and everyday life (Fifth ed.). London: Sage.

35. Goodey, J. (2008). Human trafficking sketchy data and policy responses. Criminology and Criminal Justice, 8(4), 421-442.

36. Government of the Netherlands (2016). Team work! Manual for experts on multidisciplinary cooperation against trafficking in human beings for labour exploitation. The Hague: Government of the Netherlands.

37. Gozdziak, E., \& Bump, M. (2008). Data and research on human trafficking: Bibliography of researchbased literature. Washington, D.C.: Georgetown University.

38. Hansard (2018). Commercial Sexual Exploitation. 04 July 2018. Volume 644. https://hansard.parliament. uk/Commons/2018-07-04/debates/50911795-3525-4F4A-B 047-EF 87047 B 5176 /CommercialSexualExploitation. Accessed 3/7/18.

39. HM Government, Department of Justice Northern Ireland, The Scottish Government, \& Government, W. (2018). 2018 UK annual report on modern slavery. London: HM Government.

40. HM Government. (2014). Modern Slavery Strategy. London: Her Majesty's Stationery Office.

41. HMICFRS. (2017). Stolen freedom: The policing response to modern slavery and human trafficking. London: Her Majesty's Inspectorate of Constabulary and Fire \& Rescue Services.

42. Hoff, S. (2014). Where is the funding for anti-trafficking work? A look at donor funds, policies and practices in Europe. Anti-Trafficking Review(3).

43. Home Office. (2014a). Interim review of the National Referral Mechanism for victims of human trafficking. London: Home Office.

44. Home Office. (2014b). Modern Slavery Strategy. London: Her Majesty's Stationery Office.

45. Jokinen, A., Ollus, N., \& Aromaa, K. (2011). Trafficking for forced labour and labour exploitation in Finland, Poland and Estonia. Helsinki: HEUNI.

46. Kangaspunta, K. (2003). Mapping the Inhuman Trade: Preliminary findings of the human trafficking database: UN.

47. Kelly, L. (2005). "You can find anything you want": A critical reflection on research on trafficking in persons within and into Europe. International Migration, 43(1-2), 235-265.

48. Knepper, P. (2012). Measuring the threat of global crime: Insights from research by the league of nations into the traffic in women. Criminology, 50(3), 777-809.

49. Kragten-Heerdink, S. L., Dettmeijer-Vermeulen, C. E., \& Korf, D. J. (2017). More Than Just "Pushing and Pulling": Conceptualizing Identified Human Trafficking in the Netherlands. Crime \& Delinquency, 0011128717728503.

50. Laczko, F., \& Gozdziak, E. (2005). Data and Research on Human Trafficking. In Data and research on human trafficking: A global survey. Geneva: International Organization for Migration.

51. Maroukis, T. (2017). Keeping up appearances: The British public policy response to the trafficking of domestic workers in a changing regime of social protection. Journal of Immigrant \& Refugee Studies, 15(2), 155-170.

52. McQuade, A. (2019, 10/01/19). A poisoned chalice? Challenges for the UK's next anti-slavery commissioner. Thomson Reuters Foundation. Retrieved from http://news.trust.org/item/20190110113524-3ype1 1. Accessed 5/3/19

53. National Crime Agency. (2018). Modern slavery and human trafficking: National Referral Mechanism Statistics Annual Report 2017. London: National Crime Agency.

54. National Crime Agency (in press). National Referral Mechanism. http://www.nationalcrimeagency.gov. uk/about-us/what-we-do/specialist-capabilities/uk-human-trafficking-centre/national-referral-mechanism. Accessed 24/4/18.

55. O'Connell Davidson, J. (2015). Modern slavery: The margins of freedom. Basingstoke: Palgrave Macmillan. 
56. Office for National Statistics. (2018). Crime in England and Wales: Year ending march 2018. Newport: Office for National Statistics.

57. Olver, K. (2018). 'County lines' criminal exploitation in the West Midlands, UK: professionals' perspectives on the Modern Slavery Act in practice, organisational challenges, and strengthening the collective response. MSc Dissertation, University College London, London.

58. Oram, S., Ostrovschi, N. V., Gorceag, V. I., Hotineanu, M. A., Gorceag, L., Trigub, C., et al. (2012). Physical health symptoms reported by trafficked women receiving post-trafficking support in Moldova: Prevalence. severity and associated factors. BMC Women's Health, 12(1), 1-9.

59. Oram, S., Abas, M., Bick, D., Boyle, A., French, R., Jakobowitz, S., et al. (2016). Human trafficking and health: A survey of male and female survivors in England. American Journal of Public Health, 106(6), 1073-1078.

60. Pearce, J. (2011). Working with trafficked children and young people: Complexities in practice. British Journal of Social Work, 41(8), 1424-1441. https://doi.org/10.1093/bjsw/bcr029.

61. Quirk, J. (2011). The anti-slavery project: From the slave trade to human trafficking. Philadelphia: University of Pennsylvania Press.

62. Reed, S., Roe, S., Grimshaw, J., \& Oliver, R. (2018). The economic and social costs of modern slavery. London: Home Office.

63. Rijken, C. (2011). Combatting trafficking in human beings for labour exploitation. Nijmegen: Wolf Legal Publishers.

64. Silverman, B. (2014). Modern slavery: An application of multiple systems estimation. London: Home Office.

65. Skeldon, R. (2000). Trafficking: A perspective from Asia. International Migration, 38(3), 7-30.

66. Spencer, J., \& Broad, R. (2012). The 'groundhog day'of the human trafficking for sexual exploitation debate: New directions in criminological understanding. European journal on criminal policy and research, 18(3), 269-281.

67. Surtees, R. (2008). Trafficking of men-a trend less considered: The case of Ukraine and Belarus. International Organization for Migration, Migration Research Series, 36.

68. The Anti-Trafficking Monitoring Group. (2010). Wrong kind of victim? One year on: An analysis of UK measures to protect trafficked persons. London: Anti-Slavery International.

69. The Washington Post. (2018). Fact checker: Has the sex-trafficking law eliminated 90 percent of sex trafficking ads? Glenn Kessler for The Washington Post. Retrieved from https:/www.washingtonpost. com/politics/2018/08/20/has-sex-trafficking-law-eliminated-percent-sextrafficking-ads/?noredirect= on\&utm term=.1111bfdeffa5. Accessed 5/3/19

70. Tukey, J. W. (1977). Exploratory Data Analysis (Vol. 2). Reading, mass. Pearson.

71. Tyldum, G. (2010). Limitations in research on human trafficking. International Migration, 48(5), 1-13.

72. U.S. Department of State. (2014). Trafficking in persons report June 2014. Washington, D.C.: U.S. Department of State.

73. UN (2000). United Nations convention against transnational organized crime. In UNGA (Ed.), (Vol. $\mathrm{A} / \mathrm{RES} / 55 / 25)$.

74. UNICEF. (2003). End child exploitation: Stop the traffic! London: UNICEF UK.

75. United Nations (2000). Protocol to prevent, suppress and punish trafficking in persons especially women and children. In U. Nations (Ed.). Vienna: United Nations,.

76. United Nations. (2015). Sustainable development goals: 17 goals to transform our world. New York: United Nations.

77. United Nations Office on Drugs and Crime. (2009). Trafficking in persons: A global report. Vienna: United Nations Office on Drugs and Crime.

78. United Nations Office on Drugs and Crime. (2016). Global report on trafficking in persons (p. 2016). Vienna: United Nations Office on Drugs and Crime (UNODC).

79. United Nations Statistics Division (no date). Methodology: Standard country or area codes for statistical use (M49). https://unstats.un.org/unsd/methodology/m49/. Accessed 5/3/19.

80. UNODC (2016). Global report on trafficking in persons.

81. Van Der Laan, P., Smit, M., Busschers, I., \& Aarten, P. (2011). Cross-border trafficking in human beings: Prevention and intervention strategies for reducing sexual exploitation: A systematic review. Campbell Systematic Reviews, 7(9).

82. Vincent, K., Zhang, S., \& Dank, M. (this issue). Searching for sex trafficking victims: Using a novel linktracing method among commercial sex Workers in Muzzafarpur, India. Crime, Law and Social Change. 
83. Weitzer, R. (2007). The social construction of sex trafficking: Ideology and institutionalization of a moral crusade. Politics and Society, 35(3), 447-475.

84. Weitzer, R. (2015). Human trafficking and contemporary slavery. Annual Review of Sociology, 41, 223242.

85. Zhang, S. X. (2009). Beyond the 'Natasha'story-a review and critique of current research on sex trafficking. Global Crime, 10(3), 178-195.

86. Zhang, S. X. (2012). Measuring labor trafficking: A research note. Crime, Law and Social Change, $58(4), 469-482$.

Publisher's note Springer Nature remains neutral with regard to jurisdictional claims in published maps and institutional affiliations. 